\title{
Employee Preferences for Work-life benefits in a Large New Zealand Construction Company
}

\author{
Emily Morrison, (NZIQS, New Zealand)
}

Derek Thurnell, (Unitec Institute of Technology, New Zealand)

\begin{abstract}
The construction industry is a challenging environment in which to work, with job characteristics that are linked to work-life conflict, and it is important for its future sustainability that initiatives to support employee work-life balance are undertaken. 121 head office and site-based employees within a large New Zealand construction company rated their preferences for work-life benefits, and the results were compared with those of a similar previous (Australian) study. The most preferred work-life benefit factor (as for the previous Australian study) was found to be 'wellness and personal development'. Results suggest that company provision of a wide variety of work-life benefits from which employees can choose during different stages in their life and career is ideal. Qualitative results suggest some worklife conflict associated with working long hours and weekend work exists. It is proposed that to attract and retain valuable employees, the New Zealand construction industry must provide useful work-life benefits, reasonable working hours, and supportive workplace cultures in line with such initiatives.
\end{abstract}

Keywords: Work-life balance, New Zealand, Construction company, Human resource management

\section{Introduction}

Due to its project based nature, the construction industry can be a particularly challenging environment in which to work. Jobs can be highly stressful, with pressures such as achieving tight programme deadlines, meeting the needs of multiple stakeholders, dealing with disputes, and maintaining the safety of all individuals on site (Lingard \& Francis 2004a). Furthermore, long working hours and weekend working are an integral part of many jobs in the industry. Many of these job characteristics are linked to work-life conflict, considered to be a lack of 'fit' between employees and their life responsibilities, and the goals of their organisation (Becker \& Huselid 1998). Certain workplace attributes such as work-life balance initiatives (amongst others) are related to reduced work-life conflict (Eby et al. 2005). As such, it is posited that it is important for the future sustainability of the construction industry to undertake initiatives to support employee work-life balance. Lingard and Francis (2005) assessed employee preferences for work-life balance benefits in two Australian construction companies and suggested that further study be carried out in other countries. This research surveyed managerial and professional employees' preferences for work-life benefits in a large construction company in New Zealand, and the results were analysed and compared with Lingard and Francis' (2005) findings in Australia.

\section{Work-life balance}

Work-life balance is defined as the the ability of individuals to pursue successfully their work and non-work lives, without undue pressures from one undermining the satisfactory experience of the other' (Noon \& Blyton 2007, p.356). The concept of work-life balance has evolved in response to a changing culture where work has become more demanding of both sexes and free time has become less available, in turn increasing pressures in both domains causing endemic work-life imbalance (Dallimore \& Mickel 2006; Lewis, Gambles \& Rapoport 2007; Families and Work Institute 2008). Rates of employment have increased for women and remained constant for men resulting in less time available outside of work. For some time society has been shifting away from the traditional male breadwinner model of work (Brough et al. 2008) and dual-earner households have become the norm, where both 
partners work and contribute to family responsibilities (Eby et al. 2005; Families and Work Institute 2008). Increasingly, the younger generation of working parents expect more flexible working practices and are more mindful of not over-committing themselves and achieving work-life balance (Loosemore, Dainty \& Lingard 2003; Lingard \& Francis 2004b). In addition, the percentage of single parents in the workforce has also risen, and an ageing population has resulted in an increase in elderly care demands (De Cieri et al. 2005; Families and Work Institute 2008). At the same time, work intensification has increased the pressures within the workplace. Due to these societal shifts, pressures in both work and life outside of work are at an all time high (Bardoel et al. 1999; McPherson \& Reed 2007).

The right work-life balance is different for everybody depending on their circumstances, personality, desires, and stage in life (McPherson \& Reed 2007). Moreover, work-life balance is multi-faceted and can be addressed on multiple levels (De Bruin \& Dupuis 2004). Whilst some think it is an individual issue, others believe it is a responsibility for organisations to address, or believe it should be addressed and/or regulated by government, while some believe it is a shift in societal norms that is needed (Dallimore \& Mickel 2006; Lewis, Gambles \& Rapoport 2007; Kossek, Lewis \& Hammer 2010). Purportedly, work-life research has not significantly helped improve the array of work-life balance issues that are faced by employees and employers today, and there is arguably a lack of theory and model development, a lack of exploratory research, and hence a lack of understanding of why certain relationships exist (Eby et al. 2005).

In response to the above-mentioned societal changes and increasing work-life conflict, employers have begun implementing work-life benefits; these initiatives are aimed at helping improve work-life balance. Work-life benefits can be broken down into subsets; four work-life balance categories have been identified: flexible work arrangements; leave arrangements; dependent care assistance, and general services (Frone 2003).

Implementing work-life balance policies which accommodate a diverse range of employees purportedly leads to having higher quality employees, which in turn increases company performance and competitive advantage (Kossek et al. 2010). Work-life balance policies attract and maintain employees, which leads to cost savings through decreased turnover, and if work-life benefits contribute to reduced stress, reduced work-life conflict, and increased well-being, the whole organisation experiences improved performance (Casper \& Buffardi 2004; Eby et al. 2005; Kossek et al. 2010). However, 'there is a lack of consensus about whether the positive effect of work-life benefits is universal (i.e. experienced by all employees, irrespective of their individual characteristics or circumstances) or whether the effect of work-life benefits differs for particular sub-populations of employees' (Lingard \& Francis 2005, p.1047).

What employees say they prefer, and what employees actually do once the options are available, can be different, and evidence of a gap between the organisational provision of work-life balance initiatives and actual employee usage of the initiatives has recently emerged. Utilisation is dependent not only on availability, but also on other issues, such as organisational support. The difference in uptake is possibly due to the perceived level of supportiveness of the workplace culture for using such policies (De Cieri et al. 2005; Dallimore \& Mickel 2006; Brough et al. 2008). People often do not use benefits because they feel that usage may have a negative effect on their career path; therefore it is key that management communicate and make clear their objectives and expectations (Thornthwaite 2004).

\section{Work-life balance in New Zealand}

Work-life balance issues in New Zealand are similar to those reported internationally. A New Zealand national work-life balance survey found that just over half of employees experienced work-life balance, but a significant number of employees experienced work-life conflict, and

Morrison, E and Thurnell, D (2012) 'Employee preferences for work-life benefits in a large New Zealand construction company', Australasian Journal of Construction Economics and Building, 12 (1) 12-25 
found it difficult to achieve work-life balance for a variety of reasons. A major source of conflict was that many people worked long hours and unpaid additional hours, and that many New Zealanders would like more time away from work and flexible start and finish times (Department of Labour 2006).

Most of the research on work-life balance focuses on alternative work arrangements with far less research on wellness, care-giving support, and crisis assistance. In New Zealand, flexible work hours and location are the work-life benefits most often offered, followed by work and life information, while child/elderly care is offered significantly less often (Kossek et al. 2010). Findings from a 2008 survey of New Zealand employers showed an increase in the uptake and awareness of work-life benefits overall since the previous 2006 survey (Equal Employment Opportunities Trust 2008). However, there are perceived barriers to implementation of work-life benefits in New Zealand, the largest being 'needing everyone in the workplace at the same time' and being 'too complicated' (Department of Labour 2006, p. 36).

The results from a survey of New Zealand companies showed that benefits were able to be implemented over a diverse range of businesses, that organisational culture was important for their success, and that communication from managers was important for employee awareness and use of the benefits. From the organisation's perspective, the policies had to be economically sustainable and were important for retaining dedicated employees (New Zealand Business Council for Sustainable Development 2006). These findings reinforce those of other work-life balance studies which suggest that there is no one-size-fits-all policy that works across all business (Yasbek 2004; Lingard \& Francis 2005).

\section{Work-life balance in the Construction Industry}

Interestingly, much of the work-life balance research has occurred within the Australian construction industry, due to the substantial amount of works from the same authors (see Lingard \& Sublet 2002; Francis 2004; Lingard \& Francis 2004a, 2004b, 2005, 2009; Lingard 2008; Lingard et al. 2008; Mackenzie 2008; Brown et al. 2009; Lingard, Francis \& Turner 2010a, 2010b).

A survey of employees in professional and managerial roles within the Australian construction industry indicated that workplaces were not perceived to be supportive of the need to balance work with life outside of work, and it is suggested that work-life balance policies are virtually ineffective if the organisational culture does not strongly value such initiatives (Francis 2004). Furthermore, Townsend et al. (2006) found that employees think work-life balance problems do exist in the construction industry. They suggested that reform should happen in the following areas: government and/or organisation regulation of working hours; formal work-life balance policies and informal support by supervisors; and employee control over working time.

Turner, Lingard and Francis (2009) identified workplace culture, project resourcing, and schedule demands as barriers to achieving work-life balance in the construction industry, and identified collaborative project alliance contracts, flexible working hours, and project management support as supports.

A respondent in research carried out in Australia with a focus on wellbeing in commercial construction appositely summarises the construction industry working environment with regard to work-life imbalance: 'people in the industry....are collectively weary and generally sad about the personal cost they endure as a consequence of their work... ongoing pressure that has a detrimental impact on physical and mental wellbeing, are taking a serious toll...unrealistic programming appears to be the root cause of work/life conflict' (MacKenzie 2008, p. 53).

Morrison, E and Thurnell, D (2012) 'Employee preferences for work-life benefits in a large New Zealand construction company', Australasian Journal of Construction Economics and Building, 12 (1) 12-25 
Judging by the Australian research, there is a significant amount of work-life imbalance in the construction industry. However, extensive research on work-life balance in the construction industry in New Zealand does not exist. As Lingard and Francis (2005) asserted, knowledge about employees' preferences for work-life benefits can aid in the development of effective work-life balance initiatives, and this research aimed to investigate this, so that the needs of employees in the New Zealand construction industry are better understood.

\section{Research Objectives}

This research aimed to identify employee preferences for work-life benefits within a large New Zealand construction company, and compare the results with those of a similar study undertaken within two large Australian construction companies (Lingard \& Francis 2005). Therefore, the research design was based on that of Lingard and Francis' (2005) study, and was carried out in a broadly similar manner in order to ensure that the data was comparable. There is a dearth of research regarding which types of work-life benefits employees in the New Zealand construction industry prefer, and knowledge about employees' preferences may help people within the construction industry better understand the wants and needs of employees.

\section{Research Context: Lingard and Francis' (2005) Research}

Lingard and Francis (2005) collected data from professional and managerial employees of two different organisations (a large private civil engineering and building construction company, and a public sector organisation involved in large infrastructure construction) to measure employees' preferences for work-life benefits. Their results were compared according to gender, age, and family structure; they concluded that 'distinct sub-populations of employees differ in terms of their preferences for work-life benefits. In particular, employees' preferences differ according to their age and stage of family development' (Lingard \& Francis 2005, p.1055).

\section{Research Methods}

\section{Data Collection}

Due to constraints regarding accessibility and permission, an opportunity sample of employees within one large New Zealand construction company was used. The company is relatively large, and is involved across all construction industry sectors and regions of New Zealand. By using an opportunity sample from one construction company, generalisations may not be valid; the generalisability of the findings to other large New Zealand construction companies would depend on how similar the companies are. However, collecting data from one company was considered appropriate, as this has advantages, for example 'that context variables such as organisational culture, policies and procedures are controlled' (Lingard \& Francis 2004b, p. 21).

All the company's professional and managerial staff in the Auckland region were emailed with the questionnaire instrument. The email included a description of, and reason for, the survey. The first page of the survey contained a consent clause to which the respondent was required to agree before carrying out the survey.

\section{Questionnaire Design}

Section 1 was made up of closed questions which requested demographic information. No questions were mandatory; that is, there were no forced responses. Section 2 comprised twenty closed questions where respondents were asked to rate their preference for a variety of work-life benefits using a 5 point Likert scale where: $1=$ not at all useful, $2=$ of limited use, $3=$ moderately useful, 4=useful, 5=very useful. Based on Lingard and Francis' (2005) study, the work-life benefit items were drawn from a wide variety of sources (Biggs 1998; Scheibi \& Dex 1998; Moen et al. 1999; Grandey 2001; Hill et al. 2001; Saltzein et al. 2001; Thornwaite 
2002, all as cited in Lingard \& Francis 2005). As with Lingard and Francis' (2005) study, participants were asked to ignore the likelihood of future usage when indicating their preferences. Two open questions were included at the end of the questionnaire, where employees could provide additional feedback and suggest additional work-life balance initiatives.

To avoid the need for additional ethics approvals, not all of the demographic questions from Lingard and Francis' (2005) study were used; to avoid asking respondents to reveal information that was considered to be too personal, respondents were not asked to reveal family status and birthplace. Demographic information collected from respondents included: age; gender; number of years worked in the construction industry; type of employment (full, part time or contract); job role, and work location (site-based or head office).

\section{Data Analysis}

Employees' perceptions of the utility of each of the twenty work-life benefits rated in Section 2 were analysed by determining their mean rating scores and standard deviations. Mean rating scores were also calculated for the four different categories of work-life benefit, based on the factors established by Lingard and Francis (2005) - 'childcare support', 'alternative work arrangements', 'crisis assistance/support', and 'wellness and personal development'. The mean scores of the four factors, firstly overall, then by age and gender, were then compared with Lingard and Francis' (2005) results. Mean scores were also analysed by work location (i.e. head office and site-based), which was not done in Lingard and Francis' (2005) study. A content analysis was carried out on the qualitative data; the responses to the open questions were coded by topic, and were considered in the discussion to assist in drawing inferences regarding the results from section 2 of the questionnaire.

\section{Findings}

\section{Demographic Information}

Of a possible 174 respondents, 121 complete and usable questionnaires were returned (a $70 \%$ response rate). Table 1 shows the demographic characteristics of the sample.

\begin{tabular}{|c|c|c|c|c|c|}
\hline Age & $\mathbf{n}$ & $\%$ & Type of employment & $\mathbf{n}$ & $\%$ \\
\hline Under 30 years & 22 & 19 & Full-time work & 104 & 92 \\
\hline 30-39 years & 30 & 25 & Part-time work & 2 & 2 \\
\hline $40-49$ years & 31 & 26 & Contract work & 7 & 6 \\
\hline $50-59$ years & 26 & 22 & & & \\
\hline \multirow[t]{2}{*}{60 years +} & 10 & 8 & Work location & & \\
\hline & & & On site & 85 & 71 \\
\hline \multicolumn{3}{|l|}{ Gender } & Head office & 35 & 29 \\
\hline Male & 108 & 90 & & & \\
\hline \multirow[t]{2}{*}{ Female } & 12 & 10 & Job description & & \\
\hline & & & Project managers* & 40 & 33 \\
\hline \multicolumn{3}{|c|}{ Years worked in construction } & Foremen, site managers & 8 & 7 \\
\hline $0-9$ & 35 & 30 & Site administration & 8 & 6 \\
\hline $10-19$ & 27 & 23 & Commercial managers ${ }^{* *}$ & 41 & 34 \\
\hline $20-29$ & 28 & 23 & Engineering services & 7 & 6 \\
\hline \multirow[t]{2}{*}{30 years +} & 29 & 24 & Upper management & 6 & 5 \\
\hline & & & Other & 11 & 9 \\
\hline
\end{tabular}

Table 1 Demographic characteristics of sample $(n=121)$

* includes project, construction, site, and package managers and project leaders

** includes commercial managers, quantity surveyors and estimators

Morrison, E and Thurnell, D (2012) 'Employee preferences for work-life benefits in a large New Zealand construction company', Australasian Journal of Construction Economics and Building, 12 (1) 12-25 
The mean age of the sample was undeterminable as responses were only given according to age bracket. The modal age was 40-49 years. Of the 120 responses to the question on gender, $108(90 \%)$ were male while only $12(10 \%)$ were female. Only $17 \%$ of females were over 50 years of age, whereas $32 \%$ of males were over 50 years of age, a gender distribution which indicated a younger cohort of females in general, similar to the gender/age profile in Lingard and Francis' (2005) study. There was also a similar gender mix to that of Lingard and Francis' (2005) study (which had 88\% males and 12\% females). The low proportion, yet younger cohort of females suggests that these large construction companies are still largely male dominated, but that more females may be starting to enter the industry.

Considering the number of years worked in construction, a relatively even distribution of respondents existed. Of the 113 responses regarding type of employment, the vast majority (104 respondents) had full-time working arrangements. Site-based employees made up $71 \%$ of respondents, while $29 \%$ were based off-site (in the head office). The largest groups of employees were quantity surveyors, estimators, and commercial managers $(34 \%$ of respondents), and project managers, construction managers, site managers, package managers, and project leaders (33\% of respondents).

\section{Work-life benefit Preference Mean Scores}

The mean preference scores and standard deviations of each work-life benefit (based on respondents ratings of how useful they thought each benefit would be for them personally) are shown in Table 2. The 4 factor groupings based on those identified by Lingard and Francis (2005) are also indicated.

The five benefits perceived to be the most useful overall had the smallest standard deviations, which indicated that they were not only the most preferred, but also the most agreed upon by employees. Four of the five lowest scoring benefits had relatively large standard deviations, which indicated that there was less agreement regarding employee preference for these benefits; in other words they possessed a greater variation in perceived utility.

That the highest overall mean score was for 'allowing for flexible work e.g. starting and finishing half an hour earlier or later' is not surprising, as flexible working arrangements relating to hours have been reported as by far the most desired (for $91 \%$ of New Zealanders) work-life benefit (Department of Labour 2006; McPherson \& Reed 2007). The qualitative data reinforces this, as a relatively large number of comments regarding flexible working options were made by respondents. There is evidence to suggest that providing such worklife benefits could be beneficial on many levels. Having more time-flexible working options has been linked to employee loyalty, fewer missed deadlines, and decreased stress and time off work (Halpern 2005). Furthermore, flexible workplaces have higher rates of employee job engagement, job satisfaction, intention to stay with the company and mental wellbeing (Families and Work Institute 2008).

The high mean scores for 'allowing for special family leave e.g. to care for a sick dependent' (4th highest mean score), and 'offering temporary part time work options during a family crisis' (5th highest) lend support to other findings from New Zealand which describe a demand for a wider scope of flexible work options including 'career breaks, extended maternity and paternity leave, paid dependency leave, job share, subsidised health-care and leave for community, sports and volunteer work' (New Zealand Business Council for Sustainable Development 2006, p.3). One respondent from the present study recognised some of the adverse effects of a successful career in the industry, and pointed out that the changing workforce and subsequent provision of more flexible working arrangements may have positive effects for all employees:

Morrison, E and Thurnell, D (2012) 'Employee preferences for work-life benefits in a large New Zealand construction company', Australasian Journal of Construction Economics and Building, 12 (1) 12-25 
'The key issue in construction is that our personalities are generally "goal driven". To achieve success... requires intense focus. This tends to fill our industry with [people] who leave behind them a trail of broken relationships whether with spouse or children or family. ...the industry has been dominated by men over most of [my career] and the "absent" workaholic father has been extremely common. As more women have entered the workforce, child care issues have become more prevalent. These may force more flexible working habits that are useful for all employees.'

\begin{tabular}{|c|c|c|c|}
\hline Factor & Work-life benefit & $\begin{array}{l}\text { Mean } \\
\text { value }\end{array}$ & $\begin{array}{l}\text { Standard } \\
\text { deviation }\end{array}$ \\
\hline $\mathbf{W}$ & $\begin{array}{l}\text { Allowing for flexible work hours e.g. starting and finishing } \\
\text { half an hour earlier or later }\end{array}$ & 4.23 & 1.00 \\
\hline $\mathbf{W}$ & $\begin{array}{l}\text { Reimbursing the costs of work related courses and } \\
\text { further study }\end{array}$ & 4.13 & 1.04 \\
\hline $\mathbf{W}$ & $\begin{array}{l}\text { Providing a wellness programme i.e. health checks, } \\
\text { guest speakers, fitness challenges }\end{array}$ & 4.05 & 0.87 \\
\hline $\mathrm{Cr}$ & $\begin{array}{l}\text { Allowing for special family leave e.g. to care for a sick } \\
\text { dependent }\end{array}$ & 4.02 & 1.03 \\
\hline A & $\begin{array}{l}\text { Offering temporary part time work options during a } \\
\text { family crisis }\end{array}$ & 3.91 & 1.04 \\
\hline Ch & Providing scholarships for employees' children & 3.85 & 1.41 \\
\hline $\mathbf{W}$ & $\begin{array}{l}\text { Offering a fitness programme e.g. discounted gym } \\
\text { memberships }\end{array}$ & 3.6 & 1.14 \\
\hline Cr & $\begin{array}{l}\text { Providing an employee assistance programme for } \\
\text { employees with family problems }\end{array}$ & 3.5 & 1.20 \\
\hline $\mathrm{Cr}$ & Ensuring people take their annual leave regularly & 3.36 & 1.13 \\
\hline $\mathrm{Cr}$ & Providing a legal information service & 3.23 & 1.07 \\
\hline Ch & Providing child care facilities & 3.12 & 1.47 \\
\hline Ch & Offering extended parental leave & 3.1 & 1.49 \\
\hline Ch & Providing care for children during school holidays & 3.08 & 1.48 \\
\hline Ch & Providing assistance with child care costs & 3.08 & 1.54 \\
\hline Ch & $\begin{array}{l}\text { Offering care on short notice for a child or other } \\
\text { dependents }\end{array}$ & 3.08 & 1.39 \\
\hline A & $\begin{array}{l}\text { Increasing flexibility in work location e.g. working from } \\
\text { home/telecommuting }\end{array}$ & 3.07 & 1.39 \\
\hline $\mathrm{Cr}$ & $\begin{array}{l}\text { Providing an information and referral service to assist } \\
\text { with care of dependent children }\end{array}$ & 2.88 & 1.35 \\
\hline $\mathrm{Cr}$ & $\begin{array}{l}\text { Providing an information and referral service to assist } \\
\text { with care of elderly parents }\end{array}$ & 2.61 & 1.36 \\
\hline A & $\begin{array}{l}\text { Offering part time work options e.g. approximately } \\
\text { 25hrs/week }\end{array}$ & 2.59 & 1.35 \\
\hline A & $\begin{array}{l}\text { Introducing job sharing where one job is split between } 2 \\
\text { people working fewer hours }\end{array}$ & 2.13 & 1.15 \\
\hline
\end{tabular}

Table 2 Work-life benefit preference scores (with factors indicated) Key:

\begin{tabular}{|c|l|}
\hline $\mathrm{W}$ & $=$ Wellness and personal development \\
\hline $\mathrm{Cr}$ & $=$ Crisis assistance $/$ support \\
\hline $\mathrm{A}$ & $=$ Alternative work arrangements \\
\hline $\mathrm{Ch}$ & $=$ Childcare support \\
\hline
\end{tabular}

Considering the wider scope of flexible work options, it might then be expected that the following benefits would have received higher ratings as well: 'offering extended parental leave' (12th highest mean score), 'increasing flexibility in work location e.g. working from

Morrison, E and Thurnell, D (2012) 'Employee preferences for work-life benefits in a large New Zealand construction company', Australasian Journal of Construction Economics and Building, 12 (1) 12-25 
home/telecommuting' (16th ), 'offering part time work options e.g. approximately $25 \mathrm{hrs} /$ week' (19th), and 'introducing job sharing' (lowest mean score). There are likely to be different reasons for these unexpectedly low scores, although it is impossible to decipher the reasons for these due to the nature of survey. The fact that $90 \%$ of respondents were men may have influenced the scores for 'offering extended parental leave', 'offering part time work options', and 'introducing job sharing', since traditionally and typically it tends to be women who reduce their working hours to care for dependents, by, for example, 'taking career breaks or seeking part-time employment while children are young' (Lingard \& Francis 2009, p.129). Hence a large proportion of men may not find these benefits very useful.

The second highest mean score of the benefit 'reimbursing the costs of work related courses and further study' is not unexpected, as the provision of this benefit is highly valuable. Company funding of work-related courses and continuing education is likely to be useful to a wide-ranging, large number of employees, as the high mean rating score and low standard deviation indicate. Similarly the third highest mean score for 'providing a wellness programme i.e. health checks, guest speakers, fitness challenges' is also likely to appeal to a large number of employees from various demographic groups. In support of the quantitative data, there were a relatively large number of qualitative responses (9 out of 41) expressing interest in health and fitness initiatives. As one respondent said: 'fitness incentives can create good team bonding and are a very worthwhile method of making people aware of what they are missing out on and also help a greater work / life balance.'

\section{Work-life benefit Factors}

Table 2 earlier showed the mean preference scores for the 20 benefits, together with the 4 factor groupings. The benefits were grouped into factors in order to gain insight into whether certain categories of benefits might be more useful to employees overall, and by different demographic groupings. The factors as defined by Lingard and Francis' (2005) study were relied upon for the research. Table 3 provides a direct comparison of the mean values and standard deviations for the four factors.

\begin{tabular}{|l|c|c|c|c|}
\hline \multirow{2}{*}{\multicolumn{1}{|c|}{ Factor }} & \multicolumn{2}{c|}{ Mean value } & \multicolumn{2}{c|}{ Standard deviation } \\
\cline { 2 - 5 } \multicolumn{1}{c|}{$\begin{array}{c}\text { L\&F } \\
(2005)\end{array}$} & $\begin{array}{c}\text { Current } \\
(2011)\end{array}$ & $\begin{array}{c}\text { L\&F } \\
(2005)\end{array}$ & $\begin{array}{c}\text { Current } \\
(2011)\end{array}$ \\
\hline Wellness and personal development & 3.39 & 4.00 & 0.92 & 1.04 \\
\hline Crisis assistance/ support & 2.51 & 3.44 & 0.93 & 1.23 \\
\hline Alternative work arrangements & 2.41 & 3.17 & 1.06 & 1.44 \\
\hline Childcare support & 1.95 & 3.17 & 1.12 & 1.47 \\
\hline
\end{tabular}

Table 3 Comparison of work-life benefit factor preferences

(after Lingard and Francis 2005)

'Wellness and personal development' rated as the most useful overall factor, with the lowest standard deviation, followed by 'crisis assistance/support', then 'childcare support' and 'alternative work arrangements' (which were both jointly least preferred factors). It is important to note that, although these were least preferred, the value of the mean rating score still indicates that respondents perceived those benefits to be slightly more than 'moderately useful'. 'Wellness and personal development' having the highest mean score is not surprising; benefits that fall into this category are likely to be useful to a wide range of employees, and their family structure, age, or gender may not significantly limit how useful they are. There were many qualitative comments supporting the usefulness of benefits in this category.

Morrison, E and Thurnell, D (2012) 'Employee preferences for work-life benefits in a large New Zealand construction company', Australasian Journal of Construction Economics and Building, 12 (1) 12-25 
As shown in Table 3 above, the results regarding the factors' relative importance and variation in standard deviations are strikingly similar to Lingard and Francis' (2005) results. Interestingly, judging from the mean values, all of the factors showed a slightly lower score in Lingard and Francis' (2005) Australian study, which, on face value, suggests that the Australian respondents found all of the factors slightly less useful than the respondents in the current (2011) New Zealand study. This difference may be real, but also may be due to other factors, such as cultural differences in terms of interpreting or expressing preference using the rating scale, as well as perhaps that employees' awareness in general of work-life benefits has been raised in the interim period between Lingard and Francis' (2005) study and the current (2011) study. Notably, the standard deviations in both studies got larger as the mean values decreased. This indicates that, in both studies, 'wellness and personal development' was not only rated as most useful, but respondents were also in the highest amount of agreement regarding the utility of this factor compared to the others.

\section{Comparisons by Age}

A comparison of both studies' mean values of respondent preferences for work-life benefit factors by age is presented in Table 4.

\begin{tabular}{|c|c|c|c|c|c|c|c|c|c|c|}
\hline & \multicolumn{10}{|c|}{ Mean value } \\
\hline & \multicolumn{2}{|c|}{$<30$ years } & \multicolumn{2}{|c|}{$30-39$ years } & \multicolumn{2}{|c|}{$40-49$ years } & \multicolumn{2}{|c|}{$50-59$ years } & \multicolumn{2}{|c|}{$60+$ years } \\
\hline & $\begin{array}{l}\text { L\&F } \\
2005\end{array}$ & $\begin{array}{c}\text { Current } \\
2011\end{array}$ & $\begin{array}{l}\text { L\&F } \\
2005\end{array}$ & $\begin{array}{c}\text { Current } \\
2011\end{array}$ & $\begin{array}{c}\text { L\&F } \\
2005\end{array}$ & $\begin{array}{c}\text { Current } \\
2011\end{array}$ & $\begin{array}{c}\text { L\&F } \\
2005\end{array}$ & $\begin{array}{c}\text { Current } \\
2011\end{array}$ & $\begin{array}{c}\text { L\&F } \\
2005\end{array}$ & $\begin{array}{c}\text { Current } \\
2011\end{array}$ \\
\hline $\bar{W}$ & 3.68 & 4.43 & 3.49 & 4.03 & 3.37 & 4.05 & 3.09 & 3.67 & 2.82 & 3.75 \\
\hline $\mathrm{Cr}$ & 2.44 & 3.2 & 2.39 & 3.7 & 2.55 & 3.45 & 2.82 & 3.5 & 2.05 & 3.1 \\
\hline$A$ & 2.49 & 3.34 & 2.51 & 3.46 & 2.06 & 3.02 & 2.57 & 2.98 & 1.83 & 2.95 \\
\hline $\mathrm{Ch}$ & 1.76 & 2.72 & 2.16 & 3.85 & 2.22 & 3.44 & 1.62 & 2.79 & 1.07 & 2.34 \\
\hline
\end{tabular}

Table 4 Comparison of work-life benefit preferences for different age cohorts (after Lingard and Francis 2005)

Key:

\begin{tabular}{|c|l|}
\hline W & $=$ Wellness and personal development \\
\hline $\mathrm{Cr}$ & $=$ Crisis assistance $/$ support \\
\hline $\mathrm{A}$ & $=$ Alternative work arrangements \\
\hline $\mathrm{Ch}$ & $=$ Childcare support \\
\hline
\end{tabular}

'Wellness and personal development' was by far the most preferred factor for all age cohorts in both studies. Although relative importance of the 'wellness and personal development' factor among age cohorts is not identical between the two studies, they are very similar. Employees in the 'under 30 years' age group expressed the strongest preference for the factor 'wellness and personal development' in both studies. Age cohorts 30-39 and 40-49 preferred the factor slightly less, and the age groups 50-59 and 60+ preferred the factor less than those younger than 50 years of age. This indicates a general diminishment of importance for this factor with age. In both studies, the 60+ age cohort expressed the least interest in 'alternative work arrangements', 'crisis assistance support', and 'childcare support'. The 30-39 year age cohort expressed the greatest interest in these three factors, but this was not the case in Lingard and Francis' (2005) study (although compared with the other age cohorts, the 30-39 age group did show a relatively strong preference for these factors in their study).

That the order of preference for various benefits varied by age group indicates that the utility of different benefits varied with age. For example, 'childcare support' was found to be the least preferred factor for the 50-59 year and 60+ age brackets, whereas it was found to be

Morrison, E and Thurnell, D (2012) 'Employee preferences for work-life benefits in a large New Zealand construction company', Australasian Journal of Construction Economics and Building, 12 (1) 12-25 
the second most useful factor for the 30-39 year age cohort, behind 'wellness and personal development'. This was to be expected, as respondents were asked to rate the benefits according to how useful they thought that they would be to them personally, and respondents over 50 years of age are likely to have far fewer needs for childcare support than the 30-39 year age group.

\section{Comparisons by Gender}

A comparison of both studies' mean values of respondent preferences for work-life benefit factors by gender is presented in Table 5 .

\begin{tabular}{|l|c|c|c|c|}
\hline \multirow{2}{*}{ Work-life benefit Factor } & \multicolumn{4}{|c|}{ Mean value } \\
\cline { 2 - 5 } & \multicolumn{3}{|c|}{ Female } & \multicolumn{3}{c|}{ Male } \\
\cline { 2 - 5 } & L\&F & Current & L\&F & Current \\
& 2005 & 2011 & 2005 & 2011 \\
\hline Childcare support & 1.74 & 3.71 & 1.58 & 3.09 \\
\hline Alternative work arrangements & 2.89 & 3.95 & 2.33 & 3.08 \\
\hline Crisis assistance/ support & 2.4 & 3.82 & 2.51 & 3.39 \\
\hline Wellness and personal development & 3.84 & 4.29 & 3.84 & 3.97 \\
\hline
\end{tabular}

Table 5 Comparison of preferences for work-life benefit by gender (after Lingard and Francis 2005)

In both studies, both genders expressed their highest preference for the factor 'wellness and personal development'. Females expressed a higher preference for all factors, whereas this was not the case in Lingard and Francis' (2005) study. This difference may be due to a different make-up of respondents' family structures between the two studies (although this cannot be explored as this research did not request information regarding respondents' family structure, due to ethics approval constraints). Employees with partners and dependent children in Lingard and Francis (2005) preferred the childcare support benefits the most, whereas those without dependent children preferred them the least. This may explain why females in the current research rated 'childcare support' the lowest; as this female cohort were generally younger than the males, they are less likely to have children. The relative importance of factors was the same in each study. This once again shows that the perceived usefulness of different types of benefits varied amongst the different demographic groups.

\section{Comparisons by Work location}

Table 6 shows the mean preference scores for each of the work-life benefit factors by work location. No comparison can be made with Lingard and Francis' (2005) study, as they did not analyse their results by work location.

\begin{tabular}{|l|c|c|}
\hline \multirow{2}{*}{\multicolumn{1}{|c|}{ Factor }} & \multicolumn{2}{c|}{ Mean value } \\
\cline { 2 - 3 } & Site based $(\mathbf{n = 8 6})$ & Head office $(\mathbf{n = 3 5})$ \\
\hline Wellness and personal development & 3.97 & 4.08 \\
\hline Crisis assistance/ support & 3.46 & 3.38 \\
\hline Alternative work arrangements & 3.16 & 3.19 \\
\hline Childcare support & 3.14 & 3.18 \\
\hline
\end{tabular}

Table 6 Work-life benefit factor preferences mean scores for different work locations

The relative importance of the 4 factors was identical for site $(n=86)$ and head office $(n=35)$ based employees. Although the head office employees' scores were slightly higher (i.e. they found the factors slightly more useful) than those of site-based employees, this finding suggests that the benefits are apparently valued equally by employees in both work

Morrison, E and Thurnell, D (2012) 'Employee preferences for work-life benefits in a large New Zealand construction company', Australasian Journal of Construction Economics and Building, 12 (1) 12-25 
locations, and that differences in preference for the various benefits does not stem from the type of working environment, but may be more associated with respondents' demographic characteristics such as age, gender, and family structure. Since site-based employees tended to work longer hours than head office employees, it might have been expected that site-based employees might show a stronger preference for work-life benefits, but the results did not support such a presumption.

\section{Open Questions}

Answers to one or both of the optional open ended questions were provided by 41 out of 121 respondents. Having more social events including sport, recreation, and entertainment (with and without family), was suggested by twelve respondents. More fitness initiatives such as weight loss programmes, sponsored events, and incentives were suggested by nine respondents. The third most discussed topic (mentioned by seven people) regarding worklife balance initiatives was the need for reduced working hours and/or reduced weekend work. Flexible work options such as flexible working hours were considered desirable by six respondents.

\section{Work-life benefits - Implications of Findings}

The quantitative results indicate that employee preferences for different types of work-life benefits varied among different demographic groups. These findings are in agreement with a conclusion from Lingard and Francis' (2005) study which stated that 'there is no "one size fits all" solution to work-life balance in the construction industry' (p. 1053). Although the provision of a multitude of work-life benefits is desirable, initiatives can be expensive for companies to implement. Because of this, organisations tend to offer different work-life benefits to reflect the particular needs of employees (Bardoel et al. 1999).

Qualitative responses showed employee interest in a wide variety of different work-life benefits, the most prevalent being: social events; fitness and health initiatives; reduced working hours/weekend work, and flexible work options. As suggested by Townsend et al. (2006) 'employee voice presents as an important resource for managers and policy-makers in determining work-life balance policies for industry, workplaces and individual employees' (p. 2). Information retrieved from employees can provide valuable insight for companies who wish to understand the needs and preferences of their workforce.

It is important to note that the provision of work-life benefits alone is not effective without other supports in place. A large body of research (Eaton 2003; De Cieri et al. 2005; Dallimore \& Mickel 2006; Smith \& Gardner 2007; Kossek et al. 2010) shows that if an organisation wants to provide effective and usable work-life benefits, it is extremely important to ensure that the organisational culture, managers and supervisors show support for such initiatives. Employee perception of organisational support for an individual's worklife balance has been related to increased job satisfaction and reduced work pressure, both of which reduce leaving intention (Forsyth \& Polzer-Debruyne 2007).

\section{Conclusions}

Many of the findings are consistent with those of Lingard and Francis (2005), the most significant being that the strongest preference by work-life benefit factor, both overall and within the various demographic groups, was for 'wellness and personal development'. It is likely that this is the case because these work-life benefits are appropriate for a wide variety of demographic groups. Furthermore, as with Lingard and Francis (2005) findings, employees' preferences for work-life benefits vary among different demographic groups. Consistent with other studies, these findings support the notion that there is no "one-size-fitsall' policy appropriate for all companies or group of employees, and that the provision of a wide variety of work-life benefits from which employees can choose during different stages in their life and career is ideal.

Morrison, E and Thurnell, D (2012) 'Employee preferences for work-life benefits in a large New Zealand construction company', Australasian Journal of Construction Economics and Building, 12 (1) 12-25 
The results suggest that there is some work-life conflict associated with working long hours and weekend work. It is important that the New Zealand construction industry continues to address these issues in order to find a balance that is suitable to employees, companies, and the industry as a whole, so as to provide and maintain sustainable working environments.

As with Lingard and Francis' (2005) study, this research relied upon respondents' subjective reports of their preferences for different work-life benefits. It did not attempt to ascertain whether or not such benefits would actually be used, and, if so, what impact their use would have. Further research could address whether or not employees feel the organisational culture, supervisors and managers support the work-life benefits provided by the company, and investigate whether employees are aware of all available benefits, and how they are used. Furthermore, the study did not explore employee perceptions of their own work-life balance or conflict. Future research could investigate the prevalence of work-life balance or conflict according to job role and location.

\section{References}

Bardoel, E.A., Moss, S.A., Smyrnios, K. and Tharenou, P. (1999) 'Employee characteristics associated with the provision of work-family policies and programs', International Journal of Manpower, 20, 563-576

Becker, B. and Huselid, M. (1998) 'High performance work systems and firm performance: a synthesis of research and managerial implications', Research in Personnel and Human Resources Management, 16, 53-101

Brough, P., Holt, J., Bauld, R., Biggs, A. and Ryan, C. (2008) 'The ability of work-life balance policies to influence key social/organisational issues', Asia Pacific Journal of Human Resources, 46, 261-274

Brown, K.A., Ling, S., Bradley, L.M., Lingard, H. and Townsend, K. J. (2009) 'What about me? Avoiding fatigue and gaining personal time in the work to leisure transition in work-life balance initiatives', In proceedings of the 23rd Annual Australia and New Zealand Academy of Management Conference (ANZAM 2009), 1-4 December, Melbourne

Casper, W.J. and Buffardi, L.C. (2004) 'Work-life benefits and job pursuit intentions: the role of anticipated organizational support', Journal of Vocational Behavior, 65, 391-410

Dallimore, E. and Mickel, A. (2006) 'Quality of life: obstacles, advice, and employer assistance', Human Relations, 59 (1), 61-103

De Bruin, A. and Dupuis, A. (2004) 'Work-life balance?: insights from non-standard work', New Zealand Journal of Employment Relations, 29 (1), 21-37

De Cieri, H., Holmes, B., Abbott, J. and Pettit, T. (2005) 'Achievements and challenges for work/life balance strategies in Australian organizations', International Journal of Human Resource Management, 16 (1), 90-103

Department of Labour (2006) Work-life balance in New Zealand: A snapshot of employee and employer attitudes and experiences, viewed $20^{\text {th }}$ May 2011 http://www.dol.govt.nz/worklife/research/work-life-balance.asp

Eaton, S.C. (2003) 'If you can use them: flexibility policies, organizational commitment and perceived performance', Industrial Relations, 42, 145-167

Eby, L.T., Casper, W.J., Lockwood, A., Bordeaux, C. and Brinley, A. (2005) 'Work and family research in IO/OB: content analysis and review of the literature (1980-2002)', Journal of Vocational Behavior, 66, 124-197

Equal Employment Opportunities Trust (2008) EEO Trust work-life survey, viewed $13^{\text {th }}$ May 2011 http://www.eeotrust.org.nz/research/worklife.cfm 
Families and Work Institute (2008) 2008 National study of the changing workforce, viewed $18^{\text {th }}$ March 2011 www.familiesandwork.org/site/work/workforce/2008nscw.html

Forsyth, S. and Polzer-Debruyne, A. (2007) 'The organisational pay-offs for perceived worklife balance support', Asia Pacific Journal of Human Resources, 45, 113-123

Francis, V. (2004) 'Supportive organisational cultures and their effect on male engineers', The Australian Journal of Construction Economics and Building, 4, 1-9

Frone, M.R. (2003) 'Work-family balance', in Quick, J.C. and Tetrick, L.E. (eds), Handbook of Occupational Health Psychology, American Psychological Association, Washington, D.C., 143-162

Halpern, D. F. (2005) 'How time-flexible work policies can reduce stress, improve health, and save money', Stress \& Health: Journal of the International Society for the Investigation of Stress, 21, 157-168

Kossek, E.E., Lewis, S. and Hammer, L.B. (2010) 'Work-life initiatives and organizational change: overcoming mixed messages to move from the margin to the mainstream', Human Relations, 63 (1), 3-19

Lewis, S., Gambles, R. and Rapoport, R. (2007) 'The constraints of a 'work-life balance' approach: an international perspective', International Journal of Human Resource Management, 18, 360-373

Lingard, H. (2008) 'An exploration of the adaptive strategies of working families in the Australian construction industry', Engineering Construction \& Architectural Management, 15, $562-579$

Lingard, H. and Francis, V. (2004a) A Quantitative Study of Work-life Experiences in the Public and Private Sectors of the Australian Construction Industry, Queensland University of Technology, Brisbane

Lingard, H. and Francis, V. (2004b) 'The work-life experiences of office and site-based employees in the Australian construction industry', Construction Management \& Economics, 22, 991-1002

Lingard, H. and Francis, V. (2005) 'The decline of the 'traditional' family: work-life benefits as a means of promoting a diverse workforce in the construction industry of Australia', Construction Management \& Economics, 23, 1045-1057

Lingard, H. and Francis, V. (2009) Managing Work-Life Balance in Construction, Spon, London

Lingard, H., Francis, V. and Turner, M. (2010a) 'Work-family enrichment in the Australian construction industry: implications for job design', Construction Management \& Economics, 28, $467-480$

Lingard, H., Francis, V. and Turner, M. (2010b) 'The rhythms of project life: a longitudinal analysis of work hours and work-life experiences in construction', Construction Management \& Economics, 28, $1085-1098$

Lingard, H. And Sublet, A. (2002) 'The impact of job and organizational demands on marital or relationship satisfaction and conflict among Australian civil engineers', Construction Management \& Economics, 20, $507-521$

Lingard, H. C., Townsend, K., Bradley, L. and Brown, K. (2008) 'Alternative work schedule interventions in the Australian construction industry: a comparative case study analysis', Construction Management \& Economics, 26, 1101-1112

Loosemore, M., Dainty, A. and Lingard, H. (2003) Human Resource Management in Construction Projects, Spon, London 
MacKenzie, S. (2008) A Close Look at Work and Life Balance/Wellbeing in the Victorian Construction Sector, Report for the Building Industry Consultative Council, Reinventing the Image Steering Committee, Equilibrium Work-life Solutions, Melbourne

McPherson, M. and Reed, P. (2007) 'Work-life balance in the New Zealand context', in Waring, M. and Fouche, C. (eds.) Managing Mayhem: Work-life Balance in New Zealand, Dunmore Publishing, Wellington

New Zealand Business Council for Sustainable Development (2006) Work-life Balance Report: How Member Companies are Addressing Work-life Balance, Viewed 17th December 2010 http://www.dol.govt.nz/worklife/research/work-life-balance.asp

Noon, M. and Blyton, P. (2007) The Realities of Work, Palgrave, Basingstoke

Smith, J. and Gardner, D. (2007) 'Factors affecting employee use of work-life balance initiatives', New Zealand Journal of Psychology, 36 (1), 3-12

Thornthwaite, L. (2004) 'Working time and work-family balance: a review of employees' preferences', Asia Pacific Journal of Human Resources, 42 (2), 166-184

Townsend, K., Bailey, C., Brown, K., Bradley, L. and Lingard, H. (2006) 'How would employees 'construct' a balance between work and non-work life? Work-life balance in the construction industry', in Procs 14th International Employment Relations Association Conference, Hong Kong. Viewed $7^{\text {th }}$ May 2011 http://eprints.qut.edu.au/9137/

Turner, M., Lingard, H. and Francis, V. (2009) 'Work-life balance: an exploratory study of supports and barriers in a construction project', International Journal of Managing Projects in Business 2 (1), 94 - 111

Yasbek, P. (2004). The Business Case For Firm-level Work-life Balance Policies: a Review of the Literature, Report for the Department of Labour. Viewed $17^{\text {th }}$ November 2010 http://www.dol.govt.nz/PDFs/FirmLevelWLB.pdf 